\title{
PUBLIC TRANSPORT INTEGRATION
}

The importance of the issue of an effective mode of passenger transport is currently increasing. On the one hand there is an increasing economic demand for public passenger transport, on the other hand, there is a growing traffic share of individual automobile transport. The aim of this article is to define the importance of public passenger transport and to identify the problems of its operation. The integration of different modes of public passenger transport is proposed as a way to increase the competitiveness of public passenger transport. This paper analyses the individual elements of integration systems abroad and suggests the methodology of integration system applicable in regions where the share of public passenger transport is decreasing within the transport market.

Keywords: Integration, public transport, integration barriers, organisational integration, operational integration, physical (material) integration.

\section{Introduction}

EU transport strategy prefers the transport of passengers by public passenger transport to the individual transport because the use of public passenger transport results in meeting all the goals of the EU strategy in the field of road safety. It relates mainly to the stabilization of the increased road transport claims on infrastructure whose expansion is problematic especially in built-up areas. Construction of a new expressway infrastructure caused by increasing transport operation is a long-standing problem due to the ageing of the population in the EU. The support of public passenger transport brings lower fuel consumption. This is the way how to attain another objective of the EU strategy in the field of transport that is the reduction of the EU's dependence on crude oil as a raw material that needs to be imported into the EU. Emission of air pollutants is another strategic goal that is fulfilled due to less diesel fuel consumption [1]. Based on the above considerations it has been concluded that the strategic objectives of the EU transport policy are achieved when population uses the public passenger transport. In this regard it has to be noted that it is necessary to support the public passenger transport and its competitiveness in relation to the individual automobile transport [2]. The aim of this paper is to identify the importance of public passenger transport and to define the effective method of creating the integrated transport systems.

\section{The importance and problems of public transport}

"Transportation is often referred to as the lifeblood of cities and regions because it provides the essential link of constantly moving population in this area, thereby helping to shape the region" [3]. To promote the sustainable and livable urban environmnents, private, public and non-motorised transport must functionally complement each other by forming balanced integrated systems.

However, in many cities today, transportation is characterised by the dominance of the cars, it means that there is a high auto-dependence in travel [4]. As long as there is sufficient infrastructure available (road and parking), the cars offer convenience of travel to travellers [5]. The increase of individual automobile transport in towns causes a decrease in travel speed, irregularity of public transport operation and it has also an impact on passengers in public transport. There is also congestion that prevents the accessibility to the destination points, especially those that are located in the city centre. The increase of individual automobile transport causes other problems such as decreasing road safety, increasing air pollution, traffic noise and global warming [6 - 7] While providers of public passenger transport operate only the key areas and places in certain territories, the car users benefit from a high quality of transportation in terms of availability and time. Car users usually do not consider the use of land and emission produced by road transport as a problem [8].

\footnotetext{
* ${ }^{1}$ Milos Poliak, ${ }^{1}$ Michaela Mrnikova, ${ }^{2}$ Marek Jaskiewicz, ${ }^{2}$ Rafal Jurecki, ${ }^{3}$ Barbora Kaciakova

${ }^{1}$ Faculty of Operation and Economics of Transport and Communications, University of Zilina, Slovakia

${ }^{2}$ Department of Automotive Vehicles and Transportation, Kielce University of Technology, Poland

${ }^{3}$ The Institute of Lifelong Learning, University of Zilina, Slovakia

E-mail: michaela.mrnikova@fpedas.uniza.sk
} 
However, individual transport causes static problems, too. Parked vehicles are often obstacles for pedestrians, cyclists and the disabled [9]. Concerning these problems, the key issue is to cause a change in people's mobility behaviour towards lower car usage and to encourage them to travel using public means of transport, use more bikes and walk [10]. While operators serve key origins and destinations, it is too costly for them to provide direct service between all points and it is essential to coordinate different modes of transport in order to ensure smooth, convenient transport services involved in the transfer of passengers [11]. To minimise the public passenger transport time, which is greatly influenced by passenger transfer, the integration of public passenger transport aimed at coordinating and promoting the continuous passenger transportation and providing high quality services is required. Generally speaking, many definitions of public passenger transport integration can be found in literature, e.g. Hine [12], Ibrahim [13], Dydkowski [14], Hull [15], Preston [16], but the most popular are those formulated by Nosal and Solecka [17]:

- Integration is the organisational process, in which the elements of public transport system (network and infrastructure, fares and tickets, information and marketing, etc.) served by various operators, who use different modes of transport, interact more efficiently and closely. This results in general improvement in travel conditions and quality of service.

- Integration is the way in which the individual elements of public transport are embedded in the chain of movement.

Commonly, in the urban public transport services, the word 'integration'is used for solutions that guarantee a continuity of a "door to door" services [18]. Urban transport is to provide attractive chain of services in the relationship "door to door", making integration to be defined as the combination of [17]:

- different means of public transport,

- public and individual transport,

- transport policy with other policies concerning the spatial planning or investment in infrastructure.

Speaking of the public transport integration, we can take into consideration the Mohring effect that was defined in 1972: "If more passengers use public transport, the costs per passenger are lower. It means better transport services with shorter waiting time, denser network of routes and bus stops and shortening of walking time. Due to more passengers it is allowed to plan express links in order to reduce the distance travelled by a vehicle" [19]. At present the most significant factors in supporting the integration of public transport are road safety and the impact of transport on the environment. The integration of public transport is the latest trend in Western Europe that assumes the increase of attractiveness of public passenger transport [4] and the quality of public transport services. On the basis of public passenger transport integration, it is possible to develop a unified system that provides passengers with compatible timetables for different modes of transport. The integration also plays an important role in social policy. According to Nielsen [20] the importance of transport integration creates an efficient transport system that leads to the reduction of traffic congestion and contributes to the protection of the environment. In practice, especially in Eastern Europe, it is often about the integration of fares, services and providing information [21]. According to Preston [16] this kind of integration represents only the first level of the following ones:

- integration of fares, services, terminals/bus stops and information on the public transport,

- provision of infrastructure integration, management, public and private transport pricing,

- integration of passenger and freight transport,

- integration with transport authorities,

- integration of transport measures with policy of land use planning,

- integration of general transport policy with transport education, health and social policy,

- integration of transport policy with other policies.

\section{Integration levels of public passenger transport}

According to Vuchic [3] the most important element of the increase in the number of passengers in public passenger transport is to increase the quality of service. It is required when multiple transfers and the coexistence of more than one operator lead to the necessity of coordination, cooperation and interaction among them to ensure the image of one unified system without confusing the potential users or allowing them to notice the interruption in the offered services. To define the integration of public transport it is necessary to divide it into three levels: organisational, operational and physical integration. [4].

\subsection{Organisational integration}

One of the conditions necesssary for the development of a well-integrated public transport system is that a responsible authority must be given the power to organise the integration of transport service standards [22]. The established authority is necessary due to the fact that there are several public authorities responsible for transport services in an operating area.

Urban transport serviceability is commonly provided by municipal authorities while regional transport serviceability is provided by regional authorities. For instance, in the Slovak Republic the regional bus transport is provided by the Office of self-government region - regional authority and regional rail transport is operated by the Central Government - Ministry 
of Transport. The concept of transport serviceability was originated in Hamburg, Germany in 1960.

Originating in Hamburg, the concept of an integrated organisation was established as a reaction to the declining role of transport in the city's modal split. The concept of an integrated organisation still serves as a public authority that fully coordinates transport services in the region while preserving the individual entities of the component companies which are the ones actually responsible for supplying the services [23].

Unorganised transport serviceability can result in its significant reduction as shown by the cases from Great Britain [24]. Market liberalisation in the UK in the 1980s led to the fragmentation of public passenger transport [16] which caused the reduction of public transport serviceability. At present, there are two municipalities in the UK with population of more than 1,000 people that do not have daily regular transport services [25].

Moreover, organisational integration defines the contracts between the stakeholders ensuring their interest and commitment to the performace of public transport integration system. The established authority must take into account the expectations of public transport passengers; however, according to Rivasplata [11] the authority must also consider the commercial interests of the operators in order to identify the clear objectives of integration.

\subsection{Operational integration}

Operational integration refers to the coordination and planning of the transport system with minimum interruption in space and time in order to satisfy the passengers' expectations. It consists of an integrated network layout, synchronized schedules between different modes and routes of direct transport, integrated information about all services, common fares and convenient ticketing system [26]. Greiving and Wegener [27] also highlighted the importance of transport planning. Layout intergration refers to the planning of the network without spatial discontinuities so that all routes, lines and modes are connected and coordinated in the most efficient way, allowing for convenient passengers' transfer. A clear hierarchy and structure of the system are required in combination with defined roles for each mode. Hierarchy promotes services that are easily remembered, uncomplicated, with direct routes when possible, and an efficient coverage of reliable travel routes [4]. Once the network has been harmonised, the optimisation of the system's operation requires the integration of schedules: the coordination and synchronization of arrival and departure times of the involved lines and modes. The aim is to reduce waiting, dwell-time, transfers and total travelling times. Within the operational integration it is necessary to communicate with passengers [25].

The traditional view of transport integration is that travellers perceive transfers as negative experience due to the time, costs and uncertainty [28]. That is the reason why the integrated information system is needed. All necessary information about the entire transport system must be provided, regardless of the mode used and operator responsible for the service. The way in which the network is presented to the public can significantly affect the effectiveness of the public transport system [20]. Another key issue within the operational integration is convenient ticketing system. The integrated system can increase convenience by eliminating the need to purchase a ticket for each trip. Tickets and fares establish a common integration system for the involved operators and contribute to the improvement of transport convenience allowing passengers to travel between lines by purchasing a ticket for the entire service only once. Fares have an impact on both passengers and operators. By introducing a common fare system, competition between operators can be avoided and the collected revenue can be distributed according to the signed agreements.

Some authors, e.g. Wesolowski [29], Solecka [30] separate the infrastructure integration from the operational integration and consider it as an individual element of integration.

The infrastructure integration consists of an arranged combination of elements that make up the integrity of transport network. It relates to, first and foremost, all such elements as: location of bus stops, stations and interchange junctions for convenient changing of means of transport.

\subsection{Physical integration}

According to M. Miller [31] physical or infrastructure integration relates to physical changes such as integration of new routes and reorganisation of transfers points. It refers to the planning of bus stops, stations and transfer centres, their location and facilities, as well as their design. It also involves the coordination of vehicle movements for transfers to be safe, without any conflicts between pedestrians and moving vehicles. Physical integration aims at planning the system carefully through good station designs, convenient walking paths and station amenities in order to speed up and secure transfers, improve accessibility towards and inside the intermodal transport system for all traveller groups, facilitate the users' movement and minimise the discontinuities inside the system. 


\section{Proposal of procedure for the integrated transport system implementation}

In the first stage of the proposed procedure, it is important to focus on data collection in a specified area where the integrated transport system is to be implemented. Furthermore, it is necessary to identify the common transport systems in that area. The main objective of collecting data is to gather some knowledge about supply and demand in the area concerned [6], having regard to the identification of public transport fleet and its capacity, identification of line routes, number of passengers transferred and identification of transport and transfer services.

Another important aspect is to record operating speed of vehicles that relates to fuel consumption and emissions. These two aspects can be considered as the potential benefits of the proposed integrated transport systems, as opposed to the transport systems operating at present. After defining all parameters, it is necessary to create a data collection model used for the identification of the most important areas of public transport in the region and then it is required to include these areas into integration.

Data collection is done during morning and afternoon peak hours. However, data gathered during the off-peak period are also important because it helps to identify different conditions of public transport operation. Furthermore, it is necessary to admit that data acquired on Monday and Friday are modified because the flow of passengers is not regular in these days (e.g. commuting to other cities at the beginning and end of the week).

The second stage of procedure deals with the analysis of gathered data in order to emphasise the level of travel services for passengers using different travel routes. It is possible to speak of 'an extreme' (e.g. congestion) on travel routes and lines. Consequently, it is important to identify these extremes and suggest ways to avoid them. The outcome of second stage is to determine the total supply and demand for specific lines. To summarise the capacity of all vehicles within the transport system, it is possible to identify this capacity as a supply and the number of all travellers within the system as a demand. To confim that, the traffic survey is needed.

Based on the current state of the system it is possible to propose various alternatives for implementing the integrated transport system in the third stage. According to Rodrigues a Santos [32] the alternatives are seen as hypothetical phases of a predetermined system which cannot be implemented at the same time. Alternatives are developed under the influence of certain variables that are characterised as the behaviour of all components. These alternatives should include the proposed travel routes, vehicles capacity, terminals and stops for passengers, the best combination between different modes of transport or vehicles, from the passenger's point of view as well as the operator's view.

The fourth stage of the procedure deals with the analysis of serious alternative of integration with the suggested alternative of integration. This stage is the basis for calculating the benefits of integrated transport system, taking into account the already existing system. The system is considered to be effective if it meets all the requirements in terms of public transport users, i.e. passengers, as well as system operators and society as a whole.

The overall procedure should lead to the proposal of the observed aspects of different entities: users, operators, the public, assessment of waiting time, operating costs and pollution reduction [33].

\section{Barriers of integration}

Speaking of the integration of public transport it is necessary to take into consideration some barriers. A barrier is an obstacle which prevents a given policy instrument from being implemented, or limits the way in which it can be implemented. In the extreme, such barriers may be overlooked and the resulting strategy may be much less effective. Barriers can be grouped into four main categories [34]:

- Legal and institutional barriers - these include lack of legal powers to implement a particular instrument,

- Financial barriers - these include budget restrictions limiting the overall expenditure on the strategy, financial restrictions on specific instruments, and limitations on the flexibility with which revenues can be used to finance the full range of instruments.

- Political and cultural barriers - these involve lack of political or public acceptance of an instrument, restrictions imposed by pressure groups which influence the effectiveness of instruments.

- Practical and technological barriers - while cities view legal, financial and political barriers as the most serious which they face in implementing land use and transport policy instruments, there may also be practical limitations. For expansion of public transport infrastructure, engineering designs may limit progress.

Integrated strategies are particularly effective in overcoming the second and third of these types of barrier and integration between authorities may help reduce institutional barriers as well. It is usually harder to overcome legal, institutional and technological barriers in the short term. It is often difficult to overcome a barrier without in so far reducing the performance of the overall strategy. The pursuit of synergy and the resolution of barriers are thus to some extent in conflict with the design of integrated strategies. 


\section{Conclusion}

In modern cities, individual transport leads to serious problems related to: congestion on roads and environmental pollution. With increasing performances in road transport within the insufficient capacity of road network, the possibility of traffic accident is increasing and the road safety is decreasing. Therefore, it is extremely important to strive to change people's travel behaviour towards the use of more sustainable means of transport: public transport, bicycles, walks, car sharing and carpooling. It can be achieved by using the concept of the transport demand management. The aim is to support the city inhabitants to use public means of transport. The experience gained abroad show the importance of integrated transport. The liberalised operation of public passenger transport in the UK led to the reduction of regional transport serviceability. Reduction of transport serviceability has caused the transfer of travellers to individual transport. The transport integration is not a simple process as indicated in this article. However, it is important to overcome the greatest barrier of integration - the lack of funds in public resources.The ways of obtaining financial resources is dealing Poliak et al [35].

\section{Acknowledgement}

This work was supported by the Slovak Research and Development Agency under the contract No. SK-PL-20150019 .

\section{References}

[1] KONECNY, V., GNAP J., SIMKOVA, I.: Impact of Fiscal Decentralization on Motor Vehicle Taxation in the Slovak Republic. Transport and Telecommunication J., vol. 17, No. 1, 28-39, ISSN (Online) 1407-6179, DOI: https://doi.org/10.1515/ ttj-2016-0004, February 2016.

[2] POLIAK, M.: Relationship of Reasonable Profit and Risk in Public Passenger Transport in the Slovak Republic (in Slovak), Ekonomicky casopis/J. of Economics, vol. 61, No. 2, 2013, 206-220, published by Ekonomicky ustav SAV and Prognosticky ustav SAV : Bratislava, ISSN 0013-3035.

[3] VUCHIC, V. R.: Transportation for Livable Cities, New Jersey : Rutgers, 1999.

[4] KLOTILDI, S.: Public Transport Integration: The Case Study of Thessaloniki, Transportation Research Procedia 4, 2014, 535-552.

[5] RIHA Z., TICHY, J.: The Costs Calculation and Modelling in Transport, Transport Means 2015, Kaunas : Kauno technologijos universitetas, 2015, 388-391, ISSN 1822-296X.

[6] NEDELIAKOVA, E., SEKULOVA, J., NEDELIAK, I., ABRAMOVIC, B.: Application of Raymond Fisk model in Research of Service Quality, Communications - Scientific Letters of the University of Zilina, vol. 18, No. 2, 2016, 11-14, ISSN 1335-4205.

[7] BANISTER, D.: Unsustainable Transport. City Transport in the New Century. London : Routledge, 2005.

[8] KALASOVA, A., CERNICKY, L., KUBIKOVA, S.: Microscopic Simulation of Coordinated Route in the City of Zilina, Communications - Scientific Letters of the University of Zilina, No. 2, 2014, 46-50.

[9] JELINEK, J.: Municipal Public Transport Line Modelling, Communications - Scientific Letters of the University of Zilina, No. 2, 2014, 4-8.

[10] NOSAL, K., STAROWICZ, W.: Some Problems of Mobility Management (in Poland), Transport Miejski i Regionalny, 3 , 2010.

[11] RIVASPLATA, C.: Three Perspectives on the Role of Competitive Tendering in the Integration of Public Transport, $22^{\text {nd }}$ Southern African Transport Conference (SATC), Pretoria, 2003.

[12] HINE, J.: Integration Integration Integration ... Planning for Sustainable and Integrated Transport Systems in the New Millennium, Pergamon, Transport Policy, 7, 2000.

[13] IBRAHIM, M. F.: Improvements and Integration of a Public Transport System: The Case of Signapore, Cities, vol. 20, No. 3, 2003, 205-216.

[14] DYKOWSKI, G.: Integration of Local Collective Transport (in Poland), Zeszyty Naukowe Politechniki Slaskiej, Transport, 60, 2005.

[15] HULL, A.: Integrated Transport Planning in the UK: From Concept to Reality, J. of Transport Geography, 13, 318-328, 2005.

[16] PRESTON, J.: What's so Funny about Peace, Love and Transport Integration? Research in Transportation Economics, 29, 329- 338, 2010. 
[17] NOSAL, K., SOLECKA, K.: Application of AHP Method for Multi-Criteria Evaluation of Variants of the Integration of Urban Public Transport. Transportation Research Procedia, 3, 269-278, 2014.

[18] JANIC, M., REGGIANI, A.: Integrated Transport Systems in European Union: An overview of Some Recent Developments. Transport Reviews, vol. 2, No. 4, 2001, 469-497.

[19] MOHRING, H.: Optimisation and Scale Economies in Urban Bus Transportation, American Economic Review, 62, 591e604, 1972.

[20] NIELSEN, G., et al.: HiTrans Best Practise Guide 2: Public Transport-Planning the Networks. HiTrans, 2005.

[21] POLIAK, M., SEMANOVA, S., POLIAKOVA, A.: Risk Allocation in Transport Public Service Contracts (in Poland), Ekonomski Pregled, vol. 66, No. 4, 2015, 384-403, ISSN 0424-7558.

[22] POLIAK, M., KRIZANOVA, A., SEMANOVA, S., GAJANOVA, L.: The Influence of Contract Form Choice of the Transport Services Ensuring on Performance Contracting Entity Requirement, Transport Problems = Problemy Transportu: Intern. Scientific J., vol. 9, No. 4, 2014, 153-161, ISSN 1896-0596.

[23] PUCHER, J., KURTH, S.: Verkehrsverbund: The Success of Regional Public Transport in Germany, Austria and Switzerland, (E. S. Ltd, Ed.), Transport Policy, 2, 279-291, 1996.

[24] SCHOLLER-SCHWEDES, O.: The Failure of Integrated Transport Policy in Germany: A Historical Perspective, J. of Transport Geography, 18, 2010, 85-96, 2010.

[25] POLIAK, M.: Marketing in Public Passenger Transport. Perner's Contacts [elektronic source], vol. 6, No. 4, 2011, 320-325, ISSN 1801-674X.

[26] YIU KWOK KIN, A.: An Integrated Public Transport System - A Case Study of Hong Kong, University of Hong Kong, 2005.

[27] GREIVINMG, S., WEGENER, M.: Integration of Transport and Land Use Planning: State of the Art. Proc. of the Ninth World Conference on Transport Research, Elsevier : Amsterdam, 2003.

[28] KINGHAM, S., et al.: Travelling to Work: Will People Move out of their Cars. Transport Policy, 2001, 151-160.

[29] WESOLOVSKI, J.: A City in Motion. Best Practices in the Organisation of Urban Transport (in Poland), Lodz : Instytut Spraw Obywatelskich, 2008.

[30] SOLECKA, K.: Multi-criteria Assessment of Possibilities for Integrated System of Urban Public Transport (in Poland), doctoral thesis, Politechnika Krakowska, 2013.

[31] MILlER, M. A.: Assessment of Service Integration Practices for Public Transportation: Review of the Literature, California Partners for Advanced Transit and Highways, 2004.

[32] RODRIGUES, F. A. H., SANTOS, M. P. S.: Generational Scenarios through Impact Analysis: Review of the Literature Applied to Evaluate Alternative Transport (in Portugal), Anais do IX ANPET - Congresso de Pesquisa e Ensino em Transportes, vol. 2, 1995, 442-454, Sao Carlos.

[33] VASCONCELlOS, S. C.: Plan of Integration of Transport Systems in Rio de Janeiro (in Portugal), Tese de M.Sc., PET/ COPPE/UFRJ, Rio de Janeiro, 2002.

[34] MAY, A. D., KARlstorm, A., MARler, N., MATTheVS, B., MinKen, H., MONZON, A., PAGE, M., PFAFFEBBICHLER, P., SHEPHERD, S.: Developing Sustainable Urban Land Use and Transport Strategies. A Decision Makers' Guidebook, $2^{\text {nd }}$ ed., Institute for Transport Studies : Leeds, 2005.

[35] POLIAK, M., SEMANOVA, S., VARJAN, P: The Effectivness of Suporting Public Passenger Transport from Public Funds. Transport and Communications: Scientific J., No. 1, 2016, 10-16, ISSN 1339-5130. 